\title{
Uji ketahanan galur padi terhadap wereng coklat biotipe 3 melalui population build-up
}

\author{
Resistance test of rice lines againts brown planthopper biotype 3 \\ through population build-up
}

\author{
Baehaki Suherlan Effendi*, Dede Munawar \\ Balai Besar Penelitian Tanaman Padi \\ Jalan Raya No. 9 Sukamandi, Subang 41256
}

(diterima Mei 2012, disetujui Desember 2012)

\begin{abstract}
ABSTRAK
Uji ketahanan galur terhadap wereng coklat melalui skrining massal, uji penapisan dan population build-up sangat penting untuk pelepasan varietas tahan. Tiga tahap uji ketahanan tersebut selain untuk menentukan stabilitas ketahanan, juga untuk menentukan jenis ketahanannya. Penelitian dilakukan di rumah kasa Balai Besar Penelitian Tanaman Padi Indonesia pada musim tanam 2007, menggunakan wereng coklat biotipe 3 yang telah dipelihara sejak tahun 1994 pada varietas IR42 (bph2). Varietas/ galur padi yang diuji penapisan sebanyak 18 aksesi yang agak tahan terhadap wereng coklat biotipe 3 pada skrining massal. Hasil uji penapisan menujukkan bahwa 22,2\% galur/varietas bereaksi agak tahan terhadap wereng coklat biotipe $3^{\text {up }}$, yaitu galur BP4130-1f-13-3-2*B, BP4188-7f-1-2-2*B, BP2870-4e-Kn-22-2-1-5*B, dan varietas Pulut Lewok. Pada uji pupulation buid-up galur/varietas tersebut agak tahan terhadap wereng coklat biotipe $3^{\mathrm{p}}$. Nilai indeks kehilangan funsional tanaman (functional plant loss index [FPLI]) paling rendah dimiliki oleh galur BP4130-1f-13-3-2*B dan Pulut Lewok. Indeks toleransi yang paling tinggi dimiliki oleh galur BP4130-1f-13-3-2*B dan Pulut Lewok, diikuti oleh galur BP2870-4e-Kn-22-2-1-5*B dan BP4188-7f-1-2-2*B. Indeks antibiosis Pulut Lewok paling tinggi dan tidak berbeda nyata dengan galur BP4130-1f-13-3-2*B dan indeks antibiosis paling rendah dimiliki oleh galur BP4188-7f-1-2-2*B. Varietas Pulut Lewok mempunyai pertahanan dengan antibisosis namun tidak ada toleransi terhadap wereng coklat biotipe 3. Galur BP4130-1f-13-3-2*B mempunyai pertahanan dengan adanya antibiosis dan toleransi terhadap wereng coklat biotipe 3. Galur BP4188-7f-1-2-2*B mempunyai pertahanan toleransi, tetapi tidak ada antibiosis terhadap wereng coklat biotipe 3 .
\end{abstract}

Kata kunci: galur padi, uji ketahanan, population build-up, wereng coklat

\begin{abstract}
Screening of rice lines resistance to brown planthopper (BPH) through mass screening, filtering line resistance and the population build-up are essential for the release of resistant rice varieties. In addition, the stages of the endurance are important in determining the stability of resistance, as well as the type of resistant. The research was carried out in the screen house at Indonesian Center for Rice Research in 2007. The BPH used in the research was the off spring of BPH biotype 3 that had been rearing on IR42 (bph2) variety since 1994. The result of this research showed that $22.2 \%$ of 18 lines/varieties were moderately resistant to BPH biotype $3^{\text {ft }}$ namely BP4130-1f-13-3-2*B, BP41887f-1-2-2*B, BP2870-4e- Kn-22-2-1-5*B, and Pulut Lewok. On the population build-up test, the above lines/varieties were moderately resistant to BPH biotype $3^{\mathrm{pb}}$. The low FPLI values were found in BP4130-1f-13-3-2*B and Pulut Lewok. The highest tolerance index was found on BP4130-1f13-3-2*B and Pulut Lewok followed by BP2870-4e-Kn-22-2-1-5*B and BP4188-7f-1-2-2*B. Pulut
\end{abstract}

\footnotetext{
*Penulis Korespondensi: Baehaki Suherlan Effendi. Balai Besar Penelitian Tanaman Padi,

Jalan Raya No.9 Sukamandi, Subang 41256

Tel: 0260-520157, Faks: 0260-520158, Email: baehakise@yahoo.co.id
} 
Lewok has the highest antibiosis index and is not significantly different to BP4130-1f-13-3-2*B, while BP4188-7f-1-2-2*B was lowest. Although Pulut Lewok has antibiosis defense mechanism, it is not tolerant to BPH biotype 3. The BP4130-1f-13-3-2*B line have both antibiosis and tolerant to BPH biotype 3. BP4188-7f-1-2-2*B line has tolerance character, but does not have character of antibiosis to BPH biotype 3 .

Key words: rice lines, resistance test, population build-up, brown planthopper

\section{PENDAHULUAN}

Wereng coklat biasanya menyerang tanaman padi pada musim hujan, namun serangan dimusim kemarau dimulai pada MK 1994 seluas 1 ha di Pati, pada MK1995 seluas 10 ha di Jalur Pantura, pada MK 1998 seluas 60.000 ha di Jalur Pantura (Baehaki \& Abdullah 2008). Hal tersebut terjadi karena curah hujan dan kelembaban yang tinggi di musim kemarau akibat adanya La Nina. Pada dasawarsa 2001-2010, data Ditlin menunjukkan bahwa serangan wereng coklat mencapai 360.778 ha dan 11.372 ha mengalami puso. Pada tahun 2011, serangan wereng coklat mencapai 218.060 ha dan seluas 34.932 ha diantaranya mengalami puso (Ditlin 2011 tidak dipublikasi).

Varietas IR42 (bph2) sudah patah ketahanannya terhadap wereng coklat asal Pati dan Demak dengan reaksi agak peka sampai peka, sedangkan Cisadane, Ciliwung, dan Tukad Petanu bereaksi agak tahan sampai agak peka. Varietas IR64, IR74 (Bph3), Cisadane, Sriputih, Ciherang, Bondoyudo, Kalimas, dan Membramo bereaksi agak tahan terhadap wereng coklat di lapangan (Baehaki \& Munawar 2008). Usaha merakit varietas tahan wereng coklat terus berlangsung untuk melepas padi unggul baru inbrida, hibrida, dan tipe baru sebagai target dari program pemerintah dan bahkan perusahaan swasta. Perakitan varietas tahan wereng coklat sangat sulit, terutama untuk mendapatkan varietas dengan gen tahan horizontal atau poligenik karena varietas yang banyak beredar sekarang dengan ketahanan vertikal atau monogenik.

Para pemulia padi telah mengidentifikasi 10 gen mayor tahan wereng coklat dan ketahanan ini terkait dengan gen minor yang dapat menghasilkan varietas tahan poligenik (Soundararajan et al. 2005). Pada saat dilepas tahun 1986, IR64 diberi notasi gen Bph1, namun setelah dipelajari di Balai Besar Tanaman Padi, varietas ini bukan saja tahan dalam skala laboratorium namun tahan lama di skala lapangan sehingga notasi gen tahan ditambah menjadi $\mathrm{Bph}^{+}$, notasi plus adalah ketahanan dari gen minor. Hasil penelitian Alam \& Cohen (1998) menunjukkan bahwa IR64 mempunyai gen tahan Bph1 + 7 QTLs. Hal ini menunjukkan bahwa dugaan gen minor tersebut dibuktikan sebagai quantitative trait loci (QTL) (Baehaki 2012).

Keberadaan wereng coklat biotipe 3 yang cukup lama, disebabkan oleh adanya varietas IR64 $\left(\mathrm{Bph}^{+}\right)$yang merupakan varietas durable resistance sebagai penyangga perubahan wereng coklat ke biotipe yang lebih tinggi, juga disebabkan oleh tidak berkembangnya vartietas IR74 (Bph3) yang akan menyulut terbentuknya biotipe baru. Dengan adanya IR64 dan turunan IR64, seperti Ciherang maka bitotipe 3 dapat bertahan sampai 25 tahun karena pada 2006 sudah mulai ada biotipe 4 di Asahan, Sumatera Utara (Baehaki 2010).

Ketahanan galur atau varietas padi terhadap wereng coklat diukur dengan non preferensi, antibiosis, dan toleransi, namun oleh Kogan \& Ortman (1978) diusulkan bahwa istilah non preferensi sebaiknya diganti dengan antixenosis. Mekanisme antixenosis diukur dengan kemampuan hinggap atau orientasi, sedangkan mekanisme antibiosis diukur dengan kelangsungan hidup nimfa, periode perkembangan, lama hidup imago, peningkatan populasi, dan laju makan (Soundararajan et al. 2004; Soundararajan et al. 2005). Antixenosis juga dapat diukur dari persentase nimfa yang muncul yang merupakan perbandingan telur yang diletakkan dengan nimfa yang muncul (Kaneda et al. 1982). Mekanisme toleransi dan antibiosis diukur dengan indeks kehilangan funsional tanaman (Panda \& Heinrichs 1983).

Teknik pengujian ketahanan galur padi sudah sejak tahun 1970-an dilaksanakan oleh Lembaga Penelitian Padi International (IRRI) dan negaranegara yang tergabung dalam lintas komoditi padi, termasuk Indonesia. Awal uji ketahan galur padi dilakukan dengan infestasi nimfa wereng coklat 
instar 2-3 sebanyak 10 individu per batang pada tanaman uji yang berumur 7 hari setelah semai (Heinrichs at al. 1985). Pada tahun 1987, prosedur seleksi tersebut berubah dengan menginfestasikan nimfa wereng coklat instar 2-3 sebanyak 5 individu per batang pada tanaman uji yang berumur 7 hari setelah semai (IRRI 1987; IRRI 1992). Pada tahun 1996 diterbitkan standard evaluation system for rice (SES) untuk skoring penilaian kerusakan sebagai standarisasi ketahanan padi international (IRRI 1996). Pada tahun 2000 prosedur uji berubah, yaitu dengan menginfestasikan nimfa wereng coklat instar 2-3 sebanyak 5 individu per batang pada tanaman uji yang berumur 5 hari setelah semai, dengan skor berdasar SES tahun 1996. Pada tahun 2003 sampai sekarang prosedur pengujian berubah kembali, yaitu dengan infestasi nimfa wereng coklat instar 2-3 sebanyak 8 individu per batang pada tanaman uji berumur 5 hari setelah semai (IRRI 2003; IRRI 2010), dengan sekoring penilaian kerusakan menggunakan SES 2002 (IRRI 2002)

Penelitian ini bertujuan menyeleksi galur-galur padi inbrida, hibrida, dan plasma nutfah yang tahan terhadap hama wereng coklat biotipe 3 pada skrining massal dilanjutkan dengan uji penapisan untuk stabilitas ketahanan, dan population build- up untuk informasi penyebab ketahanan melalui analisis antibiosis dan toleransi.

\section{BAHAN DAN METODE}

\section{Uji penapisan}

Uji penapisan ketahanan 18 galur/varietas padi terhadap wereng coklat dilakukan di rumah kasa Balai Besar Penelitian Tanaman Padi di Sukamandi pada musim tanam (MT) 2007. Galur padi tersebut berasal dari skrining massal sebanyak 610 galur/varietas padi inbrida, hibrida, dan tipe baru yang agak tahan terhadap wereng coklat biotipe 3 (Tabel 1). Galur-galur yang memperlihatkan ketahanan terhadap wereng coklat diuji lanjutkan ke penapisan, ditambah dengan tujuh varietas differensial, yaitu TN1, Mudgo, ASD7, Rathu Heenati, Babawee, Pokkali, dan PTB33. Rangkaian uji penapisan dan population build-up menggunakan metode Baehaki dan Abdullah (2008). Populasi wereng coklat biotipe 3 yang digunakan berasal dari populasi yang telah dipelihara sejak tahun 1994 pada varietas IR42 (bph2). Perbanyakan massal wereng coklat untuk pengujian dilakukan pada tanaman padi tersebut berumur 30 hari setelah tanam.

Benih padi disemaikan dalam kotak kayu berukuran $80 \mathrm{~cm} \times 60 \mathrm{~cm} \times 10 \mathrm{~cm}$ yang berisi

Tabel 1. Bahan uji penapisan dan population build-up

\begin{tabular}{|c|c|c|c|c|c|c|c|c|}
\hline \multirow{2}{*}{$\begin{array}{l}\text { Nomor } \\
\text { plot }\end{array}$} & \multirow{2}{*}{ Kode } & \multirow{2}{*}{ Asal } & \multirow{2}{*}{ Galur/varietas } & \multicolumn{3}{|c|}{ Ulangan (skor) } & \multirow{2}{*}{ Skor akhir } & \multirow{2}{*}{ Kriteria* } \\
\hline & & & & $\bar{I}$ & II & III & & \\
\hline$\overline{117}$ & G84 & 4358 & BP4556-1f-12-2*B & 3 & 3 & 3 & 3 & AT \\
\hline 139 & G65 & 4214 & BP4130-1f-13-3-2*B & 3 & 3 & 3 & 3 & AT \\
\hline 201 & G80 & 4292 & BP4200-2f-4-3-2*B & 3 & 3 & 3 & 3 & AT \\
\hline 214 & G37 & 4097 & BP3246-5e-Kn-25-1-3*B & 3 & 3 & 3 & 3 & AT \\
\hline 230 & G63 & 4209 & BP4128-2f-6-2-2*B & 3 & 3 & 5 & 3 & AT \\
\hline 304 & G74 & 4264 & BP4188-7f-1-2-2*B & 3 & 5 & 3 & 3 & AT \\
\hline 309 & G59 & 4192 & BP4124-1f-4-2-2*B & 3 & 5 & 3 & 3 & AT \\
\hline 321 & G20 & 4042 & BP2870-4e-Kn-22-2-1-5*B & 3 & 3 & 3 & 3 & AT \\
\hline 323 & G110 & 4493 & BP4124-1f-3-3*B & 3 & 3 & 3 & 3 & AT \\
\hline 325 & G119 & 4568 & BP3684-2e-10-1-3*B & 3 & 3 & 3 & 3 & AT \\
\hline 331 & G78 & 4279 & BP4198-4f-2-1-2*B & 3 & 5 & 3 & 3 & AT \\
\hline 428 & G94 & 4419 & ВР3244-2e-8-3-2-3*B & 3 & 3 & 5 & 3 & AT \\
\hline 429 & G79 & 4290 & BP4200-2f-3-2-2*B & 3 & 3 & 3 & 3 & AT \\
\hline 430 & G60 & 4196 & BP4124-2f-6-1-2*B & 3 & 3 & 3 & 3 & AT \\
\hline 167 & & & IR68888A/CRS117 & 3 & 3 & 5 & 3 & AT \\
\hline 168 & & & IR68897A/CRS117 & 3 & 3 & 5 & 3 & AT \\
\hline 99 & & 2208 & Ketan Ulis & 3 & 3 & 5 & 3 & AT \\
\hline 63 & & 4595 & Pulut Lewok & 5 & 3 & 3 & 3 & $\mathrm{AT}$ \\
\hline
\end{tabular}

\footnotetext{
*Keterangan: 0: sangat tahan (ST); 1: tahan (T); 3: agak tahan (AT); 5: agak rentan (AR); 7: rentan (R); 9: sangat rentan (SR)
} 
Tabel 2. Skoring ketahanan padi terhadap wereng coklat

\begin{tabular}{|c|c|c|}
\hline Skor & Gejala & Kriteria \\
\hline 0 & Tidak ada kerusakan & Sangat tahan \\
\hline 1 & $\begin{array}{l}\text { Kerusakan sangat sedikit dengan kerusakan ujung daun pertama dan } \\
\text { kedua dari tanaman uji kurang dari } 1 \%\end{array}$ & Tahan \\
\hline 3 & $\begin{array}{l}\text { Daun pertama dan kedua tanaman uji dari kebanyakan satu galur/varietas } \\
\text { menguning sebagian. }\end{array}$ & Agak tahan \\
\hline 5 & $\begin{array}{l}\text { Tanaman menguning dan kerdil jelas atau sekitar 10-25\% tanaman uji } \\
\text { dari satu galur/varietas layu. }\end{array}$ & Agak rentan \\
\hline 7 & $\begin{array}{l}\text { Lebih dari setengah tanaman uji dari satu galur/varietas layu atau mati } \\
\text { dan tanaman sisa sangat kerdil atau mengering }\end{array}$ & Rentan \\
\hline 9 & Semua tanaman uji dari satu galur/varietas mati & Sangat rentan \\
\hline
\end{tabular}

tanah Lembang. Tanah dalam kotak dibagi menjadi 3 sehingga setiap bagian lebarnya $20 \mathrm{~cm}$. Tiap-tiap galur disemaikan sebanyak 25 biji pada alur sepanjang $20 \mathrm{~cm}$ diulang 3 kali dan diletakkan secara acak. Lima hari setelah semai diadakan penjarangan dengan disisakan 20 batang setiap galur/varietas. Setiap batang diinfestasi dengan delapan individu nimfa wereng biotipe 3 instar 2-3 secara merata. Perhitungan atau skoring kerusakan dilakukan pada 7-10 hari setelah infestasi, sebab pada saat ini 90\% varietas cek rentan TN1 mati atau mati seluruhnya. Skor berdasarkan SES (IRRI 2002) (Tabel 2).

Penentuan akhir ketahanan varietas/galur padi terhadap wereng coklat didasarkan pada nilai modus dari 3 ulangan. Pertama dinilai skor kerusakan per galur pada setiap ulangan. Bila nilai modus skor berada pada nilai 0 , galur tersebut dikatakan sangat tahan (ST) atau highly resistant. Bila nilai modus skor berada pada nilai 1, galur tersebut dikatakan tahan $(\mathrm{T})$ atau resistant. Bila nilai modus skor berada pada nilai 3, galur tersebut dikatakan agak tahan (AT) atau moderately resistant. Bila nilai modus skor berada pada nilai 5, galur tersebut dikatakan agak rentan (AR) atau moderately susceptible. Bila nilai modus skor berada pada nilai 7, galur tersebut dikatakan rentan (R) atau susceptible. Bila nilai modus skor berada pada nilai 9, galur tersebut dikatagorikan sebagai sangat rentan (SR) atau highly susceptible.

\section{Population build-up wereng coklat pada galur hasil penapisan}

Uji population build-up adalah kelanjutan dari hasil uji penapisan yang dilakukan pada galur/ varietas dengan skor 0-3 pada uji penapisan. Population build-up sendiri dapat diartikan untuk melihat perkembangan populasi wereng coklat pada masing-masing galur/varietas yang memperlihatkan tahan pada uji penapisan dengan metode tidak ada pilihan makan. Hasil lebih jauh dari population build-up ini adalah untuk identifikasi antibiosis dan toleransi. Pada uji population build-up, bibit diambil dari persemaian yang tidak diinfestasi wereng coklat (hasil uji penapisan) ditambah varietas differensial pembanding TN1. Bibit-bibit padi tersebut masing-masing ditanam 1 batang pada pot berdiameter $20 \mathrm{~cm}$ dan dikurung dengan kurungan plastik berdiameter $18 \mathrm{~cm}$ dengan tinggi $80 \mathrm{~cm}$. Masing-masing diulang 5 kali.

Padi di dalam kurungan yang telah berumur satu bulan, diinfestasikan 5 pasang imago brakhiptera wereng coklat biotipe 3 yang siap bertelur. Waktu pemaparan selama 5 hari. Bila selama 5 hari ada yang mati harus diganti dengan wereng yang hidup yang umurnya sama.

Pengamatan nimfa dilakukan pada wereng coklat generasi ke-1. Nimfa instar 2-3 pada 15 hari setelah infestasi diambil dengan kantong plastik besar setinggi $1 \mathrm{~m}$, dimatikan dengan bahan kimia (campuran b.a 0,35\% tetrametrin; $0,125 \%$ d-fenotrin, dan 0,1\% d-aletrin) dan semua nimfa wereng coklat dihitung dibawah mikroskop. Nimfa-nimfa yang telah dihitung masing-masing dimasukkan pada kantong kertas dan dioven pada suhu $60{ }^{\circ} \mathrm{C}$ selama 48 jam. Tanaman padi dari masing-masing varietas dipotong pada bagian pangkal batang, selanjutnya dimasukkan pada kantong kertas, kemudian dioven pada suhu $75^{\circ} \mathrm{C}$ selama 60 jam (Baehaki et al. 2011). Berat kering tanaman dihitung dari tanaman yang normal dan tanaman yang diinfestasi wereng. Data tersebut digunakan untuk menghitung indeks kehilangan 
fungsional tanaman (functional plant loss index [FPLI]) (Panda \& Heinrichs 1983) sebagai berikut:

$$
\text { FPLI }=1-\left[\frac{\mathrm{a}}{\mathrm{b}}\right] \times\left[1-\frac{\begin{array}{c}
\text { Skor kerusakan } \\
\text { tanaman uji }
\end{array}}{9}\right] \times 100
$$

a: berat kering tanaman yang diinfestasi wereng;

b: berat kering tanaman yang tidak diinfestasi wereng.

Indeks toleransi dihitung berdasarkan nisbah berat kering wereng yang dipelihara pada tanaman uji dibandingkan dengan berat kering wereng coklat pada tanaman yang rentan dengan menggunakan formula Panda \& Heinrichs (1983) sebagai berikut:

$$
\text { Indeks toleransi }=\frac{\begin{array}{c}
\text { Berat kering nimfa wereng } \\
\text { coklat pada tanaman uji }
\end{array}}{\begin{array}{l}
\text { Berat kering nimfa wereng } \\
\text { coklat pada tanaman rentan }
\end{array}}
$$

Indeks antibiosis $=1$ - indeks toleransi

\section{HASIL}

\section{Uji penapisan}

Hasil uji penapisan menunjukkan bahwa dari 18 galur/varietas yang agak tahan pada skrining massal, hanya didapatkan 3 galur dan 1 varietas yang tetap agak tahan dengan skor 3 terhadap wereng biotipe 3 . Hal ini menunjukkan bahwa galur BP4130-1f-13-3-2*B, BP4188-7f-1-2$2 * \mathrm{~B}, \quad$ BP2870-4e-Kn-22-2-1-5*B, dan varietas Pulut Lewok mempunyai ketahanan yang stabil (Tabel 3). Galur dan varietas yang agak tahan pada uji penapisan hanya $22,2 \%$ dari 18 aksesi atau hanya $0,6 \%$ dari 610 aksesi yang diuji yang menunjukkan agak tahan pada skrining massal. Di lain pihak, sebanyak 13 galur dan 1 varietas Ketan Ulis memperlihatkan reaksi agak tahan (skor 3) terhadap wereng coklat biotipe 3 pada skrining massal, namun bereaksi agak rentan (skor 5) pada

\begin{tabular}{|c|c|c|c|c|c|c|c|c|}
\hline \multirow{2}{*}{$\begin{array}{l}\text { Nomor } \\
\text { plot }\end{array}$} & \multirow{2}{*}{ Kode } & \multirow{2}{*}{ Asal } & \multirow{2}{*}{ Galur/varietas } & \multicolumn{3}{|c|}{ Ulangan (skor) } & \multirow{2}{*}{ Skor akhir } & \multirow{2}{*}{ Kriteria* } \\
\hline & & & & $\bar{I}$ & II & III & & \\
\hline 117 & G84 & 4358 & BP4556-1f-12-2*B & 5 & 5 & 5 & 5 & AR \\
\hline 139 & G65 & 4214 & BP4130-1f-13-3-2*B & 3 & 3 & 5 & 3 & AT \\
\hline 201 & G80 & 4292 & BP4200-2f-4-3-2*B & 5 & 5 & 5 & 5 & $\mathrm{AR}$ \\
\hline 214 & G37 & 4097 & ВР3246-5e-Kn-25-1-3*B & 5 & 5 & 5 & 5 & $\mathrm{AR}$ \\
\hline 230 & G63 & 4209 & BP4128-2f-6-2-2*B & 5 & 5 & 5 & 5 & AR \\
\hline 304 & G74 & 4264 & BP4188-7f-1-2-2*B & 5 & 3 & 3 & 3 & AT \\
\hline 309 & G59 & 4192 & BP4124-1f-4-2-2*B & 5 & 5 & 5 & 5 & AR \\
\hline 321 & G20 & 4042 & BP2870-4e-Kn-22-2-1-5*B & 3 & 3 & 3 & 3 & AT \\
\hline 323 & G110 & 4493 & BP4124-1f-3-3*B & 5 & 5 & 5 & 5 & AR \\
\hline 325 & G119 & 4568 & ВР3684-2e-10-1-3*B & 5 & 5 & 5 & 5 & AR \\
\hline 331 & G78 & 4279 & BP4198-4f-2-1-2*B & 7 & 5 & 5 & 5 & AR \\
\hline 428 & G94 & 4419 & ВР3244-2e-8-3-2-3*B & 5 & 5 & 5 & 5 & AR \\
\hline 429 & G79 & 4290 & BP4200-2f-3-2-2*B & 5 & 5 & 5 & 5 & AR \\
\hline 430 & G60 & 4196 & BP4124-2f-6-1-2*B & 5 & 5 & 5 & 5 & AR \\
\hline 167 & & & IR68888A/CRS117 & 5 & 5 & 5 & 5 & AR \\
\hline 168 & & & IR68897A/CRS117 & 5 & 7 & 5 & 5 & AR \\
\hline 63 & & 4595 & Pulut Lewok & 3 & 3 & 3 & 3 & AT \\
\hline \multirow[t]{8}{*}{99} & & 2208 & Ketan Ulis & 5 & 3 & 5 & 5 & AR \\
\hline & & & Pokkali & 3 & 3 & 3 & 3 & AT \\
\hline & & & TN1 & 7 & 7 & 7 & 7 & $\mathrm{R}$ \\
\hline & & & Rathu Heenati & 3 & 3 & 3 & 3 & AT \\
\hline & & & РTB33 & 3 & 1 & 3 & 3 & AT \\
\hline & & & ASD7 & 7 & 7 & 5 & 7 & $\mathrm{R}$ \\
\hline & & & Mudgo & 5 & 7 & 5 & 5 & $\mathrm{AR}$ \\
\hline & & & Babawee & 5 & 7 & 7 & 7 & $\mathrm{R}$ \\
\hline
\end{tabular}
uji penapisan terhadap wereng coklat biotipe 3 . Uji penapisan terhadap varietas differensial

Tabel 3. Uji penapisan galur tahan wereng coklat biotipe 3

\footnotetext{
*Keterangan: 0: sangat tahan (ST); 1: tahan (T); 3: agak tahan (AT); 5: agak rentan (AR); 7: rentan (R); 9: sangat rentan (SR)
} 
sebagai varietas pembanding menunjukkan bahwa varietas TN1 (tanpa gen tahan), Babawee (bph4), dan ASD7 (bph2) bereaksi rentan, Mudgo (Bph1) bereaksi agak rentan, sedangkan Rathu Heenati (Bph3), Pokkali (Bph9) dan PTB 33 (bph2+Bph3) bereaksi agak tahan.

\section{Population build-up}

Galur atau varietas yang masuk uji population build-up adalah BP4130-1f-13-3-2*B, BP41887f-1-2-2*B, BP2870-4e-Kn-22-2-1-5*B, dan varietas Pulut Lewok, dan didampingi dengan varietas differensial rentan, yaitu TNI.

Hasil population build-up wereng coklat biotipe 3 menunjukkan bahwa galur BP4130-1f13-3-2*B, BP4188-7f-1-2-2*B, BP2870-4e-Kn22-2-1-5*B, dan varietas Pulut Lewok agak tahan terhadap wereng coklat biotipe 3 (Tabel 4). Populasi wereng coklat biotipe 3 pada galur BP4130-1f-133-2*B, BP4188-7f-1-2-2*B, BP2870-4e-Kn-222-1-5*B, dan varietas Pulut Lewok lebih rendah dan berbeda nyata dibandingkan dengan populasi wereng coklat pada TN1. Galur BP4130-1f-133-2*B dan varietas Pulut Lewok paling tahan terhadap wereng coklat biotipe 3 .

Berat kering wereng coklat pada galur BP41301f-13-3-2*B dan varietas Pulut Lewok lebih rendah dan berbeda nyata dibandingkan dengan wereng coklat pada TN1. Di lain pihak, berat kering wereng coklat pada BP2870-4e-Kn-22-2$1-5 * \mathrm{~B}$ dan BP4188-7f-1-2-2*B berbeda dengan berat kering wereng coklat pada galur BP41301f-13-3-2*B dan varietas Pulut Lewok (Tabel 4). Jumlah nimfa wereng coklat pada setiap galur/ varietas berbanding lurus dengan berat kering nimfa wereng pada setiap galur/varietas yang sama. Berat kering jerami dari galur BP4130-1f13-3-2*B, BP2870-4e-Kn-22-2-1-5*B, BP41887f-1-2-2*B, Pulut Lewok, dan TN1 tidak berbeda nyata satu sama lainnya.

Indeks kehilangan fungsional tanaman (functional plant loss index [FPLI]) dari masingmasing galur akibat serangan wereng coklat dengan standar kehilangan terhadap TN1 yang rentan dapat dilihat di Tabel 5. FPLI varietas TN1 paling tinggi, yaitu $100 \%$ dan berbeda nyata dengan FPLI dari semua galur/varietas lainnya. FPLI dari galur BP4130-1f-13-3-2*B mencapai 34,326\% berbeda nyata dan lebih rendah dibandingkan dengan galur BP4188-7f-1-2-2*B. Di lain pihak, FPLI dari galur BP4130-1f-13-3-2*B tidak berbeda nyata dengan galur BP2870-4e-Kn-22-2-1-5*B dan Pulut Lewok.

Indeks toleransi yang paling tinggi dimiliki oleh galur BP4130-1f-13-3-2*B dan Pulut Lewok, diikuti oleh galur BP2870-4e-Kn-22-21-5*B dan BP4188-7f-1-2-2*B. Indeks antibiosis Pulut Lewok paling tinggi dan tidak berbeda nyata dengan galur BP4130-1f-13-3-2*B. Indeks antibiosis paling rendah dimiliki oleh galur BP4188-7f-1-2-2*B (Tabel 5).

Terteranya nilai indeks toleransi dan indeks antibiosis belum dapat menentukan karakteristik

Tabel 4. Population build-up wereng coklat biotipe 3 pada galur/varietas hasil penapisan

\begin{tabular}{|c|c|c|c|c|c|c|}
\hline \multirow[b]{2}{*}{ Nomor } & \multirow[b]{2}{*}{ Kode } & \multirow[b]{2}{*}{ Asal } & \multirow[b]{2}{*}{ Galur/varietas } & \multirow{2}{*}{$\begin{array}{l}\text { Populasi nimfa } \\
\text { wereng coklat } \\
\text { (individu) }\end{array}$} & \multicolumn{2}{|c|}{ Berat kering } \\
\hline & & & & & $\begin{array}{c}\text { Nimfa wereng } \\
\text { coklat }(\mathrm{g})\end{array}$ & Jerami $(g)$ \\
\hline 139 & G65 & 4214 & BP4130-1f-13-3-2*B & $210,80 \mathrm{c}$ & $0,02634 \mathrm{~d}$ & $12,184 \mathrm{a}$ \\
\hline 304 & G74 & 4264 & BP4188-7f-1-2-2*B & $527,20 \mathrm{~b}$ & $0,10285 \mathrm{~b}$ & $9,234 \mathrm{a}$ \\
\hline 321 & G20 & 4042 & BP2870-4e-Kn-22-2-1-5*B & $390,60 \mathrm{~b}$ & $0,06388 \mathrm{c}$ & $10,394 \mathrm{a}$ \\
\hline 63 & - & 4595 & Pulut Lewok & $186,40 \mathrm{c}$ & $0,01968 \mathrm{~d}$ & $12,174 \mathrm{a}$ \\
\hline & & & TNI (tanpa gen) & $731,60 \mathrm{a}$ & 0,17112 a & $9,400 \mathrm{a}$ \\
\hline
\end{tabular}

Angka rata-rata yang diikuti huruf yang sama tidak menunjukkan perbedaan yang nyata pada taraf uji 5\% uji DMRT

Tabel 5. Karakteristik ketahanan galur terhadap wereng coklat biotipe 3

\begin{tabular}{|c|c|c|c|c|c|c|}
\hline Nomor & Kode & Asal & Galur/varietas & FPLI $(\%)$ & Indeks torelansi & Indeks antibiosis \\
\hline 139 & G65 & 4214 & BP4130-1f-13-3-2*B & $34,326 \mathrm{~d}$ & $0,1565 \mathrm{~d}$ & $0,84345 \mathrm{a}$ \\
\hline 304 & G74 & 4264 & BP4188-7f-1-2-2*B & $64,566 \mathrm{~b}$ & $0,6157 \mathrm{~b}$ & $0,38427 \mathrm{c}$ \\
\hline 321 & G20 & 4042 & BP2870-4e-Kn-22-2-1-5*B & $43,105 \mathrm{~cd}$ & $0,3855 \mathrm{c}$ & $0,61441 \mathrm{~b}$ \\
\hline \multirow[t]{2}{*}{63} & - & 4595 & Pulut Lewok & $38,208 \mathrm{~cd}$ & $0,1215 \mathrm{~d}$ & 0,87841 a \\
\hline & & & TNI (tanpa gen) & 100 & $1,00 \quad \mathrm{a}$ & $0 \quad \mathrm{~d}$ \\
\hline
\end{tabular}

Angka rata-rata yang diikuti huruf yang sama tidak menunjukkan perbedaan yang nyata pada taraf uji 5\% uji DMRT 


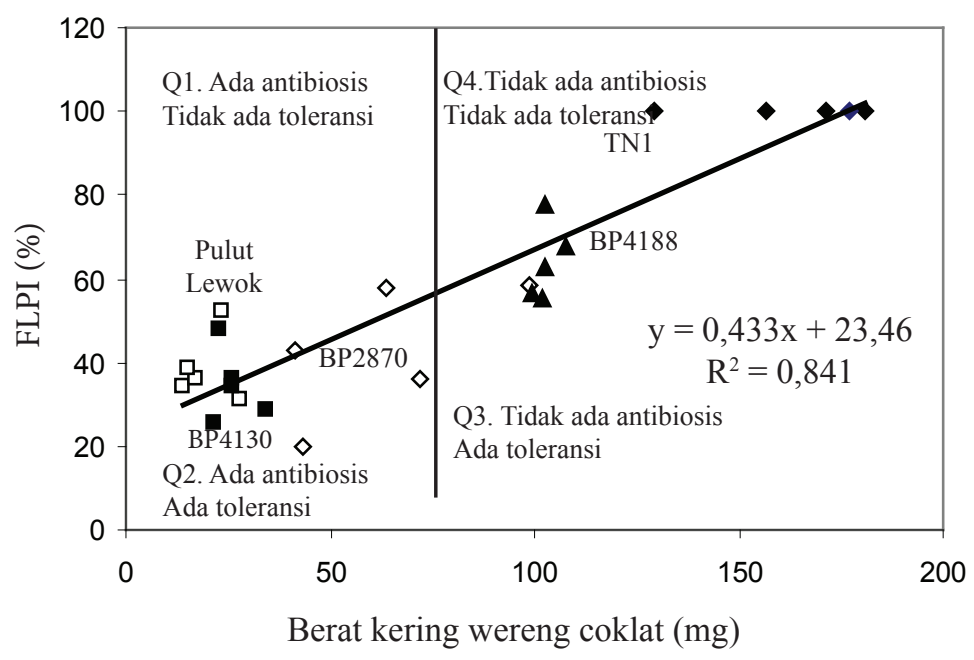

Gambar 1. Identifikasi komponen ketahanan galur/varietas terhadap wereng coklat biotipe 3 .

ketahanan galur atau varietas karena nilai yang dicantumkan adalah nilai rata-rata, sedangkan untuk menentukan karakteristik ketahanan adalah sebaran nilai indeks toleransi dan antibiosis. Oleh karena itu, untuk melihat adanya perpaduan indeks toleransi dan indeks antibiosis yang menyebabkan ketahanan maka diperlukan hubungan antara FPLI (y) dan berat kering wereng coklat (x) dari masing-masing galur atau varietas dan dihitung regresi gabungan dari seluruh galur dan varietas. Persamaan regresi gabungan adalah $\mathrm{y}=0,433 \mathrm{x}+$ 23,46 dengan $\mathrm{R}^{2}=0,841\left(\mathrm{r}_{\mathrm{df}=24}=0,388^{* *}\right)$ sangat berbeda nyata yang memungkinkan sebaran dari varietas mempunyai berbagai kombinasi dari antibiosis dan toleransi (Gambar 1). Nilai rata-rata berat kering wereng coklat $(x)=75,16$ mg sebagai variabel bebas, digambarkan dari atas ke bawah sehingga memotong persamaan garis regresi. Garis perpotongan regresi dan nilai rata-rata membuat empat quadran dengan katagori kombinasi jenis ketahanan antibiosis dan toleransi. Mekanisme ketahanan yang dimiliki galur/varietas ditentukan oleh sebaran titik koordinat $(\mathrm{x}, \mathrm{y})$ di empat katagori kombinasi tersebut. Varietas TN1 berada di quadran IV (Q4) yang menandakan varietas TN1 tidak mempunyai ketahanan baik antibiosis maupun toleransi terhadap wereng coklat biotipe 3 (Gambar 1).

Varietas Pulut Lewok berada di quadran I (Q1) mempunyai pertahanan dengan antibisosis, namun tidak ada toleransi terhadap wereng coklat biotipe 3. Galur BP4130-1f-13-3-2*B berada di quadran II (Q2) mempunyai pertahanan dengan antibiosis dan toleransi terhadap wereng coklat biotipe 3. Galur BP4188-7f-1-2-2*B berada di quadran III (Q3), yaitu galur yang tidak mempunyai pertahanan antibiosis, tetapi ada toleransi terhadap wereng coklat biotipe 3. Galur-galur BP2870-4e-Kn-22$2-1-5 * \mathrm{~B}$ sulit ditentukan karakter ketahanannya karena data hubungan FPLI dan berat kering wereng sangat menyebar ada di setiap quadran.

\section{PEMBAHASAN}

Berdasarkan pedoman uji ketahanan international network for genetic evaluation of rice (INGER) 2003 (IRRI 2003) dan berdasar SES 2002 (IRRI 2002), varietas/galur BB Padi yang telah diuji pada tahun 2007 sebanyak 610 aksesi terdiri atas padi inbrida, hibrida, dan tipe baru menghasilkan 18 galur/varietas yang agak tahan terhadap wereng coklat biotipe 3. Pada uji penapisan dari 18 galur/varietas tersebut di atas, hanya didapatkan 3 galur dan 1 varietas plasma nutfah yang bereaksi stabil agak tahan pada skrining massal dan uji penapisan terhadap wereng biotipe 3 . Galur yang agak tahan pada uji penapisan adalah BP4130-1f-13-3-2*B, BP41887f-1-2-2*B, dan BP2870-4e-Kn-22-2-1-5*B, dan varietas Pulut Lewok. Rendahnya perolehan galur yang tahan sesuai dengan hasil skrining massal tahun 2006, yang dari 200 galur yang diuji hanya didapatkan 52 galur yang tahan wereng coklat biotipe 3. Pada uji penapisan, dari 52 galur yang telah diketahui tahan pada skrining massal, hanya 7 galur yang tetap tahan terhadap wereng coklat biotipe 3 (Baehaki \& Abdullah 2008).

Pulut Lewok, BP4130-1f-13-3-2*B dan BP4188-7f-1-2-2*B mempunyai nilai FPLI rendah yang mengindikasikan varietas dan galur 
tersebut tahan terhadap wereng coklat. Varietas Pulut Lewok mempunyai pertahanan dengan adanya antibisosis, namun tidak ada toleransi terhadap wereng coklat biotipe 3. Galur BP41301f-13-3-2*B dengan FPLI yang rendah mempunyai pertahanan dengan adanya antibiosis dan toleransi terhadap wereng coklat biotipe 3, sedangkan galur BP4188-7f-1-2-2*B tidak mempunyai pertahanan antibiosis, tetapi ada toleransi terhadap wereng coklat biotipe 3. Galurgalur BP2870-4e-Kn-22-2-1-5*B sulit ditentukan karakter ketahanannya karena data hubungan FPLI dan berat kering wereng sangat menyebar ada di setiap quadran. FPLI, preferensi nimfa, nimfa yang muncul, nimfa bertahan hidup, dan indeks pertumbuhan yang rendah terjadi pada varietas tahan PTB (bph2+Bph3) dibandingkan dengan varietas rentan TN1 (Alagar et al. 2007). Telur yang tidak menetas, tanda cucukan, enzim peroksida dan polifenol oksida pada 1 hari setelah infestasi, kitinase pada 3 hari setelah infestasi lebih tinggi pada varietas tahan PTB33 dibandingkan dengan varietas rentan TNI (Alagar et al. 2007). Tanda cucukan bertanda ${ }^{32} \mathrm{P}$ kecil-kecil dengan cacahan yang rendah terjadi pada varietas tahan dibanding varietas rentan dengan tanda cucukan besar, terjadi pada kerja wereng coklat bertanda isotop ${ }^{32} \mathrm{P}$ (Baehaki 1982). Varietas tahan akan berpengaruh terhadap perkembangan nimfa karena waktu penyelesaian stadia nimfa lebih panjang pada varietas tahan PTB dibandingkan dengan varietas rentan TN1 (Alagar et al. 2007). Namun demikian, ketahanan PTB tidak hanya ditentukan oleh gen mayor bph2+Bph3, tetapi ditentukan juga oleh ketahanan gen minor QTL (Santhanalakshmi et al. 2010)

Babawee (bph4) yang yang berasal dari IRRI tahan terhadap wereng coklat biotipe $1,2,3$, dan 4 menunjukkan reaksi rentan terhadap wereng biotipe 3 dari Jawa Barat, Jawa Tengah, dan Jawa Timur (Baehaki \& Munawar 2009). Kejadian tersebut tidaklah berlebihan karena hal ini terjadi pula pada 31 tahun yang lalu, sesuai laporan Seshu dan Kauffman (1980) bahwa reaksi Babawee rentan di Vietnam dan bereaksi rentan atau tahan di India bergantung pada daerahnya. Gen bph4 tahan terhadap wereng coklat Kepulauan Solomon, Asia Selatan dan Asia Tenggara, kecuali di Indonesia yang bereaksi rentan terutama terhadap wereng 14 coklat biotipe 2 (Seshu \& Kauffman 1980). Variasi genetik populasi wereng coklat di Asia dilihat dari sekuen DNA mitokondria berbeda, yaitu wereng coklat di Bangladesh, Thailand, Vietnam, dan Malaysia adalah Haplotipe AC, wereng coklat di Filipina dan China terdiri atas tiga haplotipe AC, AA, dan GA, sedangkan di Korea adalah haplotipe AC dan GA (Mun et al. 1999). Velusamy et al. (1995) melaporkan bahwa Rathu Heenati, Babawee, ARC 10550, Swarnalata, PTB33 dengan nimfa wereng uji instar 2 sebanyak 8 individu/ batang yang diinfestasikan pada persemaian umur 7 hari bereaksi tahan (skor 1) pada 7 hari setelah infestasi (hsi), bereaksi tahan (skor 2,2-3,3) pada 11 hsi, dan bereaksi agak tahan sampai agak rentan (skor 5,4-7,4) pada 15 hsi.

Pada penelitian ini dengan SES 2002, nimfa wereng uji instar 2-3 sebanyak 8 individu/batang yang diinfestasikan pada persemaian umur 5 hari menunjukkan bahwa Babawee bereaksi rentan, sedangkan Rathu Heenati, Pokkali dan PTB 33 bereaksi agak tahan pada 9 hsi. Penafsiran skor $0,1,3,5$ yang digunakan di Indonesia dalam rangka pengetatan pelepasan varietas adalah berturut-turut sangat tahan, tahan, agak tahan dan agak rentan. Pada penelitian uji ketahanan varietas menggunakan nimfa wereng uji instar 2-3 sebanyak 10 individu/batang yang diinfestasikan pada persemaian umur 13-14, menunjukkan bahwa ASD7, Rathu Heenati, ARC 10550, dan Chin Saba (bph8) bereaksi agak rentan sampai rentan (skor > 7) terhadap wereng coklat pada 9-10 hsi (Qiu et al. 2011). Pada percobaan tersebut penafsiran skor $<3$ adalah tahan, sedangkan skor 3-5 adalah agak tahan dan 7-9 rentan sampai sangat rentan.

Data tersebut menunjukkan bahwa ketahanan varietas ditentukan oleh letak geografi asal wereng coklat, prosedur pengujian yang digunakan, penafsiran skor, dan lingkungan. Sehubungan dengan lingkungan, daya bertahan hidup nimfa, keperidian dan penetasan telur wereng coklat akan meningkat dengan meningkatnya pemakaian nitrogen yang tinggi dibanding dengan tanaman pemakaian nitrogen yang rendah ( $\mathrm{Lu}$ et al. 2005). Ketahan varietas akan berkurang bila wereng coklat beradaptasi dengan tanaman padi yang awalnya tahan, hal ini dapat diketahui dari luas embun madu (honeydew) pada varietas adaptif 
tahan IR62 (Bph3) tidak berbeda dengan embun madu pada varietas rentan TN1 (non gen tahan). Embun madu akan meningkat bila pada dua varietas tersebut diberi pupuk nitrogen dengan takaran $150 \mathrm{~kg}$ per ha (Cruz et al. 2011).

Kemampuan makan wereng coklat akan meningkat pada generasi lanjut apabila dipelihara pada varietas yang sama. Variasi dan komposisi dalam asam amino mempengaruhi kebugaran wereng coklat dan akan berubah sesuai perubahan generasi. Asam amino serin, glysin, histidin, prolin, tirosin, isoleusin, leusin, dan fenilalanin akan meningkat pada generasi 11 dibandingkan dengan generasi 8 , sedangkan konsentrasi aspartat, glutamat, alanin, valin, metionin, dan lysin menurun pada generasi 11 dibandingkan dengan generasi 8 (Chen et al. 2011). Adaptasi wereng coklat pada tanaman tahan akan merugikan karena peningkatan populasi wereng coklat akan mengurangi penyerapan $\mathrm{P}$ dan $\mathrm{K}$ oleh akar tanaman (Yin et al. 2005)

Dari uji population build-up, berat kering wereng coklat yang paling tinggi adalah pada varietas rentan TN1. Hal ini cocok sekali dengan kemampuan makan wereng coklat biotipe 3 pada varietas rentan yang lebih tinggi sehingga berat kering wereng akan lebih tinggi (Baehaki \& Abdullah 2008).

Galur-galur BP2870-4e-Kn-22-2-1-5*B sulit ditentukan karakter ketahanannya karena data hubungan FPLI dan berat kering wereng sangat menyebar dan ada di setiap quadran. Oleh karena itu, galur tersebut perlu diuji ulang dan dimasukan lagi ke seleksi massal setelah diseleksi di lapangan karena diduga galur tersebut masih segregan. Hal ini terjadi juga terhadap galur BP13561G-KN-4 dan BP205D-KN-78-1-8 yang tidak konsisten mekanisme ketahanannya sehingga perlu diperbaiki dan dimasukan lagi ke skrining massal, uji penapisan galur, dan diteliti ulang reaksinya terhadap wereng coklat (Baehaki \& Abdullah 2008). Dengan pengetatan uji ketahanan telah dihasilkan Inpari 3 dan Inpari 13 yang tahan wereng di lapangan.

Perakitan varietas tahan wereng coklat telah banyak dilakukan persilangan antara plasma nutfah baik yang berupa varietas maupun berupa galur. Galur intogresi IR65482-7-216-1-2, yang merupakan plasma nutfah hasil persilangan IR31917-45-3-2 dengan Oryza australiensis (Acc. No. 100882), teridentifikasi mengandung gen tahan Bph18 bereaksi tahan terhadap wereng coklat di Korea (Jena et al. 2006). Galur tersebut disilangkan dengan Junambyeo yang rentan dan menghasilkan galur-galur yang tahan wereng coklat (Suh et al. 2011). Galur introgresi IR547413-21-22 tahan terhadap wereng coklat biotipe India bila disilangkan dengan tetua asalnya (IR31917-45-3-2) yang rentan terhadap wereng coklat biotipe India, menghasilkan F1 yang tahan wereng coklat biotipe India (Jena et al. 2002). Hal ini terjadi karena galur introgresi IR54741-3-2122 mengandung gen dominan yang tahan wereng coklat.

Implikasi dari penelitian adalah teridentifikasi varietas Pulut Lewok yang dapat menjadi plasma nutfah yang handal untuk merakit varietas-varietas unggul baru yang tahan wereng coklat. Galur BP4130-1f-13-3-2*B dan BP4188-7f-1-2-2*B dapat dilanjutkan untuk pelepasan varietas agak tahan wereng coklat biotipe 3 setelah melalui uji multilokasi dan kualitas beras. Penelitian yang serupa menghasilkan 1 galur BP3448E-4-8 mempunyai ketahanan antibiosis dan toleransi dan dua galur yang belum stabil BP1356-IG-KN-4 dan BP205D-KN-78-1-8 (Baehaki \& Abdullah 2008) dilepas berturut-turut sebagai varietas Inpari 3, 2, dan 6 Jete. Pelepasan galur yang belum stabil pada population build-up dilakukan setelah melalui perbaikan pemulianya.

\section{KESIMPULAN}

Pada uji population build-up, galur/varietas yang tahan terhadap wereng coklat biotipe $3^{\mathrm{pb}}$ adalah BP4130-1f-13-3-2*B, BP4188-7f-1-2$2 * \mathrm{~B}$, dan BP2870-4e-Kn-22-2-1-5*B, dan varietas Pulut Lewok. Varietas Pulut Lewok mempunyai pertahanan dengan adanya antibisosis, namun tidak ada toleransi terhadap wereng coklat biotipe 3. Galur BP4130-1f-13-3-2*B mempunyai pertahanan dengan adanya antibiosis dan toleransi terhadap wereng coklat biotipe 3. Galur BP41887f-1-2-2*B mempunyai pertahanan antibiosis, tetapi tidak ada toleransi terhadap wereng coklat biotipe 3. Galur BP2870-4e-Kn-22-2-1-5*B sulit 
ditentukan karakter ketahanannya karena data hubungan FPLI dan berat kering wereng sangat menyebar ada di setiap quadran.

\section{DAFTAR PUSTAKA}

Alagar M, Suresh S, Samiyappan R, Saravanakumar D. 2007. Reaction of resistant and susceptible rice genotypes against brown planthopper (Nilaparvata lugens). Phytoparasitica 35:346356. http://dx.doi.org/10.1007/BF02980697.

Alam SN, Cohen MB. 1998. Detection and analysis of QTLs for resistance to the brown planthopper, Nilaparvata lugens, in a double haploid rice population. Theoretical and Applied Genetics 97:1370-1379. http://dx.doi.org/10.1007/s00122 0051031 .

Baehaki SE. 1982. Autoradiografi selubung stilet wereng coklat bertanda ${ }^{32} \mathrm{P}$ dalam beberapa varietas tanaman padi. Penelitian Pertanian $2: 19-22$

Baehaki SE. 2010. Perubahan biotipe wereng coklat pada beberapa sentra produksi padi di Indonesia. In: Sutrisno et al. (Eds.), Prosiding Seminar Nasional V, Pemberdayaan Keanekaragaman Serangga untuk Pengingkatan Kesejahteraan Masyarakat (Bogor, 20 Mei 2010). pp: 53-62. Bogor: Perhimpunan Entomologi Indonesia.

Baehaki SE. 2012. Perkembangan biotipe hama wereng coklat pada tanaman padi. IPTEK Tanaman Pangan 7:8-17.

Baehaki SE, Munawar D. 2008. Identifikasi biotipe wereng coklat di Jawa, Sumatera dan Sulawesi dan reaksi ketahanan kultivar padi. In: Suprihatno B et al. (Eds.), Prosiding Seminar Apresiasi Hasil Penelitian Padi Menunjang P2BN (Subang, 1920 Nopember 2007). pp 351-366. Subang: Balai Besar Penelitian Tanaman Padi, Badan Penelitian dan Pengembangan Pertanian.

Baehaki SE, Abdullah B. 2008. Evaluasi karakter ketahanan galur padi terhadap wereng coklat biotipe 3 melalui uji penapisan dan peningkatan populasi. In: Suprihatno B et al. (Eds.), Prosiding Seminar Apresiasi Hasil Penelitian Padi Menunjang P2BN (Subang, 19-20 November 2007). p367-382. Subang: Balai Besar Penelitian Tanaman Padi, Badan Penelitian dan Pengembangan Pertanian.

Baehaki SE, Munawar D. 2009. Uji biotipe wereng coklat, Nilaparvata lugens Stal di sentra produksi padi. In: Suprihatno B et al. (Eds.), Prosiding Seminar Nasional 2008 (Subang, 2008). pp. 347360. Subang: Balai Besar Penelitian Tanaman
Padi, Badan Litbang Pertanian. Departemen Pertanian.

Baehaki SE, Cohen M, Heong KL. 2011. Level and mechanism of host plant resistance in popular rice varieties: Antixenosis, antibiosis, and feeding rate of brown planthopper on various resistant rice varieties. In: Ahmad I et al. (Eds.), Prosiding Seminar Nasional PEI Cabang Bandung: Hidup Sejahtera Bersama Serangga (Bandung, 16-17 Februari 2011). pp. 97-122. Bandung: Perhimpunan Entomologi Indonesia Cabang Bandung.

Chen YH, Bernal C C, Tang J, Horgan FG, Fitzgerald MA. 2011. Planthopper "adaptation" to resistant rice varieties: Changes in amino acid composition over time. Journal of Insect Physiology 57:1375-1384. http://dx.doi.org/10.1016/j. jinsphys.2011.07.002.

Cruz A P, Arida A, Heong KL, Horgan FG. 2011. Aspects of brown planthopper adaptation to resistant rice varieties with the $B p h 3$ gene. Entomologia Experimentalis et Applicata 141: 245-257. http://dx.doi.org/10.1111/j.15707458.2011.01193.x.

[Ditlin] Direktorat Perlindungan. 2011. Laporan serangan organisme pengganggu tanaman. (unpublished).

Heinrichs EA, Medrano FG, Rapusas HR. 1985. Genetic Evaluation for Insect Resistance in Rice. Los Banos, Philippines: IRRI.

[IRRI] International Rice Research Institute. 1987. The Thirdteenhth International Rice Brown Planthopper Nursery (IRBPHN-1987). Los Banos: International Rice Research Institute.

[IRRI] International Rice Research Institute. 1992. The Eighteenth International Rice Brown Planthopper Nursery (IRBPHN-1992). Los Banos: International Rice Research Institute.

[IRRI] International Rice Research Institute. 1996. Standar Evaluation System for Rice. Los Banos: International Rice Research Institute.

[IRRI] International Rice Research Institute. 2002. Standar Evaluation System for Rice (SES). Los Banos: International Rice Research Institute.

[IRRI] International Rice Research Institute. 2003. The Twenty-Fourth International Rice Brown Planthopper Nursery (IRBPHN-2003). Los Banos: International Rice Research Institute.

[IRRI] International Rice Research Institute. 2010. The Twenty-Eighth International Rice Brown Planthopper Nursery (IRBPHN-2010). Los Banos: International Rice Research Institute.

Jena KK, Pasalu IC, Rao YK, Varalaxmi Y, Krishnaiah K, Khush GS, Kochert G. 2002. Molecular tagging 
of a gene for resistant to brown planthopper in rice (Oryza sativa L.) Euphytica 129:81-88. http://dx.doi.org/10.1023/A:1021590025240.

Jena KK, Jeung JU, Lee JH, Choi HC, Brar DS. 2006. High-resolution mapping of a new brown planthopper $(\mathrm{BPH})$ resistance gene, Bph 18(t), and marker-assisted selection for BPH resistance in rice (Oryza sativa L.). Theoretical and Applied Genetics 112:288-297. http://dx.doi.org/10.1007/ s00122-005-0127-8.

Kaneda C, Ikeda R, Jin YD. 1982. Suppression of population build-up of brown planthopper by resistant cultivars, with special emphasis on breeding lines develop through repeated backcrossings. Japanese Journal of Breeding 32:129-138.

Kogan M, Ortman EE. 1978. Antixenosis a new proposed to replace Painter's 'nonpreference' modality of resistance. Bulletin of the Entomological Society of America 24:175-176.

Lu ZX, Heong KL, Yu XP, Hu C. 2005. Effects of nitrogen on the tolerance of brown planthopper Nilaparvata lugens, to adverse environmental factors. Insect Science 12:121-128. http://dx.doi. org/10.1111/j.1744-7917.2005.00014.x.

Mun JH, Song YH, Heong KL, Roderick GK 1999. Genetic variation among Asian population of rice planthoppers, Nilaparvata lugens and Sogatella furcifera (Hemiptera: Delphacidae): mitochondrial DNA sequences. Bulletin of Entomological Research 89:245-253. http:// dx.doi.org/10.1017/S000748539900036X.

Panda N, Heinrihs EA. 1983. Levels of torerance and antibiosis in rice varieties having moderate resistance to the brown planthopper, Nilaparvata lugens (Stal) (Hemiptera: Delphacidae). Environmental Entomology 12:204-1214.

Qiu Y, Guo J, Jing S, Tang M, Zhu L, He G. 2011. Identification of antibiosis and tolerance in rice varieties carrying brown planthopper resistant genes. Entomologia Experimentalis et Applicata 141:224-231. http://dx.doi.org/10.1111/j.15707458.2011.01192.x.
Santhanalakshmi S, Saikumar S, Rao S. 2010. Mapping genetic locus linked to brown planthopper resistance in rice Oryza sativa L. Inter. Journal of Plant Breeding and Genetics 4:13-22. http://dx.doi.org/10.3923/ijpbg.2010.13.22.

Seshu DV, Kauffman HE. 1980. Differential Response of Rice Varieties to The Brown Planthopper in International Screening Tests. Los Banos: IRRI Reseacrh Paper Series. IRRI.

Soundararajan RP, Kadirvel P, Gunathilagaraj K, Maheswaran M. 2004. Mapping of quantitative trait loci associated with resistance to brown planthopper in rice by means of a doubled haploid population. Crop Science 44:2214-2220. http://dx.doi.org/10.2135/cropsci2004.2214.

Soundararajan RP, Gunathilagaraj K, Chitra N, Maheswaran M, Kadirvel P. 2005. Mechanisms and genetics of resistance to brown planthopper, Nilaparvata lugens (Stal.) in rice, Oryza sativa L. - A review. Agricultural reviews 26:79-91.

Suh JP, Yang SJ, Jeung JU, Pamplona A, Kim JJ, Lee JH. 2011. Development of elite breeding lines conffering Bph 18 gene-derived resistance to brown planthopper (BPH) by markerassisted selection and genome-wide background analysis in japonica rice (Oryza sativa L). Field Crops Research 120:215-222. http://dx.doi. org/10.1016/j.fcr.2010.10.004.

Velusamy R, Kumar MG, Edward JT. 1995. Mechanism of resistance to the brown planthopper Nilaparvata lugens in wild rice (Oryza spp) cultivars. Entomologia Experimentalis et Applicata 74:245-251. http://dx.doi. org/10.1111/j.1570-7458.1995.tb01897.x.

Yin JL, Wu JC, Yu YS, Liu JL, Xie M, Wan FH. 2005. Comparison of the effect on brown planthopper, Nilaparvata lugens (Stal) (Homoptera: Delphacidae) and rice leaffolder, Cnaphalocrosis medinalis Guenee (Lepidoptera: Pyralidae) infestation and simulated on nurient uptake by the root of rice plants. Environmental Entomology 34:1614-1620. http://dx.doi.org/10.1603/0046225X-34.6.1614. 